
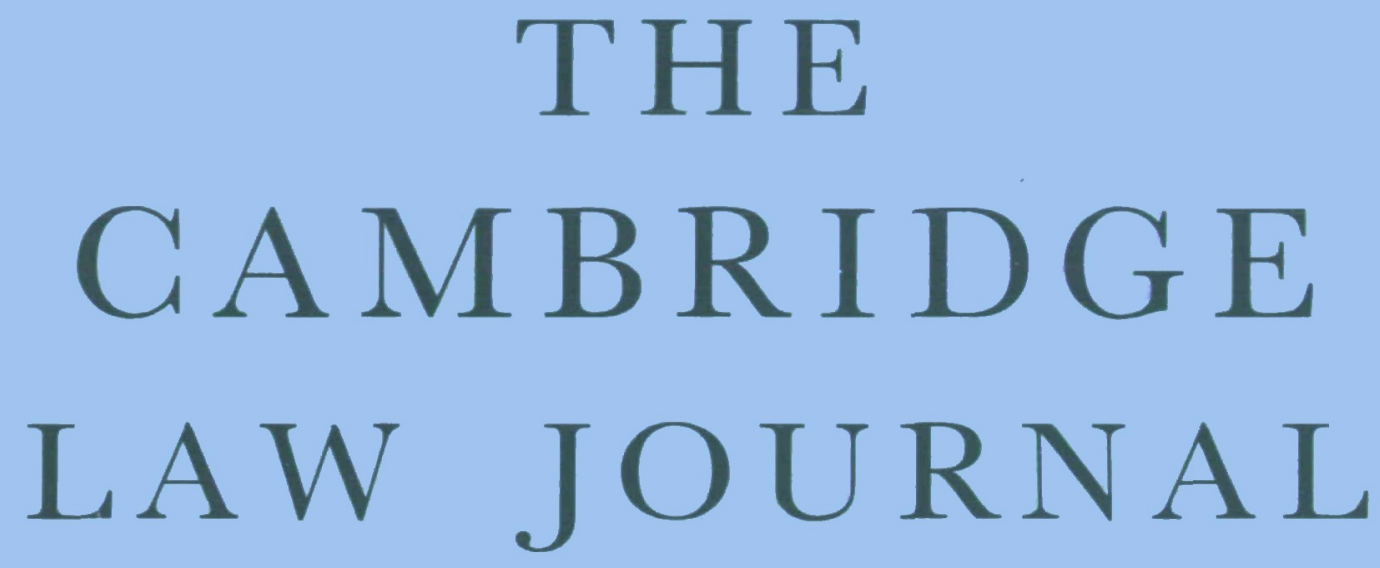

\title{
March 1990
}

Evasion of Law and Mandatory Rules in Private International Law

J.J. FAWCETT

Why Conventionalism Does Not Collapse into Pragmatism

N.E. SIMMONDS

Discretion and Security: Excluding Evidence under Section 78(1) of the Police and Criminal Evidence Act 1984

$$
\text { C.J.W. ALLEN }
$$

The Writs of Dower and Chapter 49 of Westminster I

JOSEPH BIANCALANA

Common Law Marriage

PETER LUGAS

For full contents see back cover

\section{CAMBRIDGE UNIVERSITY PRESS}




\title{
THE CAMBRIDGE LAW JOURNAL
}

EDITORIAL COMMTTTEE

\author{
C.C. Turpin, M.A., LL.B., Editor \\ M.A. Clarke, M.A., LL.B., Ph.D., Secretary and Treasurer \\ Professor J.H. Baker, LL.D., F.B.A. \\ Professor J.A. Jolowicz, M.A., Note Editor \\ Professor D.G.T. Williams, M.A., LL.B., Note Editor \\ Professor Glanville L. Williams, Q.C., LL.D., F.B.A. \\ J.G. Collier, M.A., LL.B., Note Editor \\ C.A. Gearty, Ph.D., Note Editor \\ J.C. Hall, M.A., LL.B., Note Editor \\ C. Harpum, M.A., LL.B., Note Editor \\ A.V. Lowe, Ph.D., Note Editor \\ R.J.C. Munday, M.A., Ph.D., Book Review Editor \\ M.J. Prichard, M.A., LL.B. \\ L.S. Sealy, Ph.D. \\ J.R. Spencer, M.A., LL.B., Note Editor
}

SUBSCRIPTIONS 1990

One volume of The Cambridge Law Journal (ISSN 0008-1973) is published each year. Each volume is in three parts, published in March, July and November. The subscription price of Volume 49 is $£ 24.00$ net (US\$59.00 in the USA and Canada), including postage, and is payable in advance. Reduced rate subscriptions are available to members of the Society of Public Teachers of Law and the Association of Law Teachers, law students and recently qualified lawyers. Details may be obtained from the publishers. Single parts cost $£ 11.00$ net (US\$24.00 in the USA and Canada) plus postage. Orders may be sent to any bookseller or subscription agent or to Cambridge University Press, The Edinburgh Building, Shaftesbury Road, Cambridge CB2 2RU, or in the USA and Canada to Cambridge University Press, The Journals Department, 40 West 20th Street, New York, NY 10011.

(C) The Cambridge Law Journal and Contributors, 1990

\section{BACK VOLUMES}

All back volumes are kept in print hardbound and may be purchased at the prices shown below. A discount of $10 \%$ is given on a single order for 25 or more volumes.

Vols. 1-11 (1921-1953)

one volume of 3 parts every 3 years

$£ 29-00$ per volume

Vols. 12-30 (1954-1972)

one volume of 2 parts every year

$£ 25.00$ per volume

Vol. 31 (1972) Jubilee Issue

including Index 1921-1970

$£ 29 \cdot 00$ per volume

Vols. 32-43 (1973-1984)

one volume of 2 parts every year

$£ 25.00$ per volume

Vols. 44-48 (1985-1989)

one volume of 3 parts every year

$£ 25.00$ per volume

\section{ADVERTISING}

Details of advertising in the Journal may be obtained from 